\title{
PERBEDAAN JIGSAW II DAN GI TERHADAP PEMAHAMAN KONSEP DAN PEMECAHAN MASALAH PADA KOMPETENSI MENDIAGNOSIS PERMASALAHAN PENGOPERASIAN PC DAN PERIPHERAL DITINJAU DARI MOTIVASI BELAJAR
}

\author{
Pipit Utami \\ Program Studi Pendidikan teknologi dan Kejuruan PPs UNY \\ utami.pipit@ymail.com \\ Pardjono \\ Universitas Negeri Yogyakarta \\ jpardjono@yahoo.com
}

\begin{abstract}
Abstrak
Penelitian ini bertujuan untuk mengetahui perbedaan pemahaman konsep dan pemecahan masalah pada materi KK3: (1) antara siswa yang diajar dengan pembelajaran kooperatif tipe Jigsaw II dan siswa dengan pembelajaran kooperatif tipe Group Investigation (GI) ketika motivasi belajar TKJ dikendalikan; dan (2) antara penggunaan tipe pembelajaran kooperatif (tipe Jigsaw II dan tipe GI) dengan tingkat motivasi belajar TKJ (tinggi dan rendah). Penelitian ini merupakan penelitian eksperimen semu dengan nonequivalent comparison-group design menggunakan dua kelas perlakuan sebagai variabel bebas yang diberikan pembelajaran kooperatif dengan dua tipe berbeda. Satu kelas menggunakan tipe Jigsaw II, sedangkan kelas yang lainnya diberikan tipe GI. Variabel motivasi belajar TKJ dijadikan sebagai pembagi kategori kelompok siswa yang memiliki motivasi belajar TKJ tinggi dan rendah serta sebagai kovarian. Teknik analisis data yang digunakan adalah analisis multivarian kovariat dan desain faktorial dengan progam SPSS 16. Artikel ini menunjukkan tujuan kedua, dengan hasil penelitian menunjukkan bahwa: (1) untuk pencapaian pemahaman konsep, pembelajaran kooperatif tipe Jigsaw II dan tipe GI baik diaplikasikan untuk siswa yang memiliki motivasi belajar TKJ tinggi dan rendah, akan tetapi untuk siswa yang memiliki motivasi belajar TKJ rendah lebih baik menggunakan tipe GI; dan (2) untuk pencapaian pemecahan masalah, pembelajaran kooperatif tipe Jigsaw II dan tipe GI baik diaplikasikan untuk siswa yang memiliki motivasi belajar TKJ tinggi, siswa yang memiliki motivasi belajar TKJ rendah maupun siswa yang memiliki motivasi belajar TKJ tinggi lebih baik menggunakan tipe GI.
\end{abstract}

Kata kunci: perbedaan, pembelajaran kooperatif, motivasi belajar TKJ, pemahaman konsep, pemecahan masalah

\section{THE DIFFERENCES OF JIGSAW II AND GI ON THE CONCEPT UNDERSTANDING AND PROBLEM SOLVING IN COMPETENCE OF DIAGNOSING PROBLEMS WHEN OPERATE PC AND PERIPHERAL IN TERMS OF LEARNING MOTIVATION}

\author{
Abstract
}

This research aims to describe the differences of concept understanding and problem solving on the KK3 material: (1) between students taught using the cooperative learning Jigsaw Type II and GI Type when TKJ learning motivation was controlled; and (2) between the use of cooperative learning (Jigsaw Type II and Group Investigation (GI) Type) with the levels of TKJ learning motivation (high and low). This research was quasi-experimental with the nonequivalent comparison-group design using two treatment classes as independent variables which were given cooperative learning with two different types. One class used the Jigsaw Type II while the other used the GI Type. The TKJ learning motivation was used as the divider category of students who have high and low TKJ learning motivation as well as covariant. The data analysis technique in this research was the multivariat analysis of covariate and factorial design using the SPSS 16 program. This article shows the second aim, and the results shows that: (1) for concept understanding achievement, cooperative learning Jigsaw Type II and GI Type are good to be applied for students who have high and low TKJ learning motivation, but for those who have low TKJ learning motivation, GI Type is better than Jigsaw Type II; and (2) for problem solving achievement, cooperative learning Jigsaw Type II and GI Type are good to be applied to students who have high TKJ learning motivation, where for those who have high and low TKJ learning motivation GI Type is better than Jigsaw Type II.

Keywords: differences, cooperative learning, TKJ learning motivation, concept understanding, problem solving 


\section{PENDAHULUAN}

Sekolah Menengah Kejuruan (SMK) sebagai bagian dari sistem pendidikan nasional pada jenjang menengah, menyiapkan siswanya untuk memasuki dunia kerja/industri dengan berbekal ilmu pengetahuan, keterampilan dan sikap. Sesuai dengan penjelasan UU Sisdiknas No. 20 Tahun 2003 pasal 15 yang menyatakan bahwa "pendidikan kejuruan merupakan pendidikan menengah yang mempersiapkan peserta didik terutama untuk bekerja dalam bidang tertentu". Dengan demikian SMK diharapkan dapat mempersiapkan siswanya menjadi tenaga kerja berkompeten yang dibutuhkan dalam pembangunan agar setelah lulus dari SMK, siswa dapat terserap di industri.

Akan tetapi harapan tersebut dihadapkan dengan kenyataan terkait keterserapan lulusan SMK di DU/DI yang belum optimal. Seperti yang disampaikan oleh Direktur Pembinaan SMK Joko Sutrisno, bahwa dari beberapa lapangan pekerjaan yang tersedia baru sekitar $50 \%$ yang bisa menyerap lulusan SMK. (Surabayapost, 2010). Dengan informasi tersebut, maka yang perlu diperhatikan adalah ternyata ada sebagian lulusan SMK yang tidak bisa langsung terserap di industri. Faktor yang dapat meningkatkan keterserapan lulusan SMK, salah satunya adalah dengan meningkatkan kualitas lulusan SMK. Hal tersebut senada dengan pernyataan Menteri Pendidikan dan Kebudayaan Mohammad Nuh bahwa, lulusan SMK perlu ditingkatkan, baik untuk siap bekerja maupun siap melanjutkan kuliah (Napitupulu, 2012).

Peningkatan kualitas lulusan memiliki maksud peningkatan kompetensi lulusan SMK. Agar kompetensi yang menjadi tujuan pembelajaran di SMK mampu benar-benar membekali siswa SMK di industri, maka kompetensi tersebut diselaraskan dengan kompetensi yang dibutuhkan di industri, sementara industri terdiri dari banyak bidang. Sejalan dengan hal tersebut, maka Kompetensi Keahlian yang ditawarkan di SMK tidak hanya terdiri dari satu kompetensi keahlian. Dari DitPSMK (2013), diketahui bahwa Teknik Komputer dan Informatika merupakan salah satu dari 40 program studi keahlian yang ada di SMK. Salah satu hasil penelitian Pudji Muljono (2012), menunjukkan bahwa program keahlian yang paling relevan dengan arah kebijakan pengembangan ristek adalah program studi keahlian Teknik Komputer dan Informatika. Teknik Komputer dan Jaringan (TKJ) merupakan salah satu kompetensi keahlian pada program keahlian teknologi informasi. Merujuk pada hasil penelitian tersebut, dalam penelitian ini kompetensi lulusan SMK yang coba ditingkatkan dengan menyelaraskannya dengan kebutuhan industri adalah kompetensi lulusan TKJ.

Lomba Kompetensi Siswa (LKS) SMK Tingkat DIY Bidang IT \& Network Supporting merupakan salah satu tolak ukur untuk melihat pencapaian kompetensi siswa TKJ SMK se-DIY. Pada LKS SMK Tingkat DIY Bidang IT \& Network Supporting tahun 2011, TKJ SMK 1 Sedayu memiliki perolehan nilai 33,88 yang jauh lebih rendah dari nilai peringkat 1 yaitu 83,19. Rendahnya pencapaian nilai tersebut mengindikasikan adanya permasalahan pembelajaran di TKJ SMK 1 Sedayu. Tujuan kompetensi keahlian TKJ adalah untuk menghasilkan tenaga ahli di bidang komputer yang mempunyai sikap, pengetahuan dan keterampilan yang kompeten dalam melaksanakan tugas pemasangan, perawatan, perbaikan dan instalasi jaringan komputer serta peralatan pendukung (periferal), yang meliputi pemasangan, perawatan dan perbaikan pada: (1) periferal; (2) komputer; dan (3) jaringan komputer (SMK N 1 Sedayu, 2009). Terkait dengan penggunaan Personal Computer (PC) sebagai perangkat untuk membantu banyak keperluan hampir di semua sektor pembangunan, tujuan kompetensi keahlian TKJ tersebut memiliki relevansi dengan kebutuhan dunia kerja.

Penggunaan PC yang semakin sering akan cenderung memiliki banyak kemungkinan munculnya permasalahan, maka dibutuhkan SDM yang kompeten untuk mendiagnosis permasalahan yang muncul dalam pengoperasian PC tersebut. Kemampuan mendiagnosis tersebut diperlukan untuk mengetahui langkah tepat dalam perbaikan PC yang bermasalah. Kemampuan tersebut tercantum pada unit kompetensi yang termuat dalam Standar Kompetensi Kerja Nasional Indonesia (SKKNI). SKKNI berlaku secara nasional dan menjadi acuan penyelenggaraan pendidikan. Pada kurikulum, kemampuan tersebut terdapat pada Standar Kompetensi (SK) mendiagnosis permasalahan pengoperasian PC dan periferal (KK3). Materi KK3 sendiri memiliki tingkat 
kepentingan dan keterkaitan yang sangat erat dengan materi Melakukan Perbaikan dan atau Setting Ulang Sistem PC (KK4) yang diajarkan pada semester berikutnya. Sehingga dapat diambil kesimpulan bahwa siswa TKJ perlu menguasai kompetensi materi KK3 agar berkompeten dalam mendiagnosis permasalahan pada PC.

Materi KK3 menuntut siswa menggunakan pemahaman yang telah dimilikinya untuk mendiagnosis permasalahan pada PC dan peripheral. Untuk menguasai materi KK3, terlebih dahulu siswa harus menguasai materi Merakit PC (DKK1) dan materi Melakukan Instalasi Sistem Operasi (DKK2). Pentingnya penguasaan kedua kemampuan tersebut dapat diilustrasikan dengan contoh kasus permasalahan. Misalnya ketika terdapat permasalahan berupa tidak terdeteksinya USB Flashdisk di PC, untuk mendiagnosanya, maka siswa perlu memiliki pemahaman tentang pengaturan hardware di PC dan hubungannya dalam sistem operasi yang telah dipelajari pada materi kompetensi keahlian sebelumnya (materi Merakit PC (DKK1) dan Melakukan Instasi Sistem Operasi (DKK2). Dari dasar informasi dan pengalaman pada materi tersebut, akan membantu melaksanakan prosedur mendiagnosa permasalahan dari permasalahan PC yang ditemui tersebut (materi KK3).

Hasil observasi dan wawancara di TKJ SMK 1 Sedayu menunjukkan temuan bahwa: (1) nilai yang diperoleh siswa SMK 1 Sedayu pada LKS SMK tingkat DIY tahun 2011 bidang IT \& network supporting cukup rendah; (2) sebagian besar siswa praktik industri pada awal pembelajaran di DU/DI mengalami kesulitan dalam memberikan layanan maintenance and repairing $\mathrm{PC}$; (3) nilai ulangan harian materi KK3 rendah; (4) pembelajaran di TKJ SMK 1 Sedayu belum berhasil menerapkan pembelajaran student-centerd; (5) kemampuan pemahaman konsep dan pemecahan masalah siswa terhadap materi masih kurang dan (6) dalam penentuan kelompok praktikum, siswa kurang menunjukkan adanya penerimaan terhadap seluruh warga kelas dalam bekerja sama. Dari hasil temuan tersebut dan analisis kebutuhan kompetensi yang telah dipaparkan sebelumnya, pemahaman konsep dan pemecahan masalah, penting dimiliki oleh siswa agar berkompeten pada materi KK3.
Tidak dapat dipungkiri bahwa pembelajaran merupakan salah satu faktor penting yang menentukan kualitas lulusan SMK. Pembelajaran di SMK menghendaki pencapaian kompetensi oleh tiap siswa dan memiliki karakteristik yang bersifat hands on, dalam hal ini siswa diupayakan memiliki keterampilan kerja yang sesuai. Akan tetapi hal yang juga seyogyanya tidak boleh terlupakan adalah mengenai perlunya mengupayakan karakteristik head dan heart. Hal tersebut dikarenakan bahwa diketahui siswa di SMK diupayakan minimal menguasai kriteria kompetensi minimal (KKM), dimana unsur kompetensi tersebut tidak hanya pencapaian hands on (keterampilan kerja). Hal tersebut sesuai menurut Suwarna (2006:17-18), bahwa kompetensi bersifat kompleks dan merupakan kesatuan utuh yang menggambarkan potensi, pengetahuan, sikap dan nilai yang dimiliki seseorang dalam profesi tertentu berkenaan dengan bagian-bagian yang dapat diaktualisasikan dalam bentuk kinerja untuk menjalankan profesi tersebut. Sehingga paparan ini kembali menguatkan bahwa pemahaman konsep perlu ditekankan sebagai modal awal awal untuk membangun dan memahami baik pengetahuan, keterampilan, konsep yang lebih besar maupun dalam memecahkan masalah yang muncul.

Pembelajaran untuk mencapai kompetensi siswa seharusnya dilaksanakan dengan pendekatan berpusat pada siswa (studentcenter) yang sesuai dengan teori konstruktivisme. Pendekatan ini menempatkan siswa untuk secara aktif membentuk pengetahuan, tidak sekedar menerima secara pasif dari guru. Sehingga pengetahuan tidak sekedar dipindahkan oleh guru, tetapi harus dibangun dan dimunculkan sendiri oleh siswa agar dapat berinteraksi dengan informasi yang ada. Kurang aktifnya siswa dalam pembelajaran memerlukan peran guru yang tidak hanya memberikan semua materi tanpa memberi kesempatan siswa untuk membangun pengetahuannya sendiri. Guru perlu menentukan model pembelajaran yang membantu siswa mengkonstruksi pengetahuan dengan aktif dan bekerja sama dengan oranglain untuk menciptakan hubungan sosial dan intelektual yang produktif, yaitu meningkatkan pengetahuan, hubungan sosial dan personal secara bersamaan. 
Salah satu model pembelajaran yang sesuai dengan teori konstruktivisme adalah pembelajaran kooperatif (Trianto, 2010:26). Menurut Arends (2008: 4), cooperative learning adalah model yang unik di antara modelmodel pembelajaran lainnya karena menggunakan struktur tujuan, tugas dan hadiah atau reward yang berbeda untuk mendukung pembelajaran siswa. Pembelajaran kooperatif menekankan pada diskusi atau kerja sama antara peserta didik untuk saling bertukar gagasan dan ide dalam kelompok, sehingga dalam prosesnya peserta didik akan menjadi lebih aktif (Slavin, 1995: 5). Tidak hanya aspek kerja sama yang bisa dikembangkan dalam pembelajaran kooperatif. Gillies (2007: 11) menyebutkan bahwa implementasi pembelajaran kooperatif salah satunya dapat mengembangkan higher order thinking. Pemahaman konsep dan pemecahan masalah merupakan bagian dari higher order thinking. Sehingga secara teoritis pembelajaran kooperatif secara umum mampu mengembangkan pemahaman konsep dan pemecahan masalah siswa.

Ada beberapa macam model pembelajaran kooperatif, diantaranya adalah model kooperatif spesialisasi tugas. Model tersebut sesuai dengan karakteristik pembelajaran praktikum, dimana siswa diupayakan untuk mengkonstruksi pengetahuan secara bersamasama dengan anggota kelompok dalam menyelesaikan tugas. Contoh model tersebut adalah Jigsaw II dan GI (Slavin, 2009:214). Dari paparan Slavin (2009: 215-245), pembelajaran kooperatif tipe Jigsaw II dan GI dapat mendukung pemahaman konsep dan pemecahan masalah. Penelitian-penelitian mengenai penggunaan pembelajaran koope-ratif di SMK sudah sering dilakukan. Dari uraian tersebut, dapat disimpulkan bahwa pembelajaran kooperatif tipe Jigsaw II dan tipe GI bisa diupayakan untuk pengembangan pemahaman konsep dan pemecahan masalah materi KK3.

Selain penggunaan model pembelajaran yang tepat, dalam pembelajaran, perlu juga diperhatikan faktor-faktor lain yang dapat mempengaruhi proses dalam pembelajaran. Faktor-faktor tersebut secara tidak langsung mempengaruhi pencapaian kompetensi. Salah satu faktor tersebut adalah motivasi. Peranan motivasi adalah dalam hal penumbuhan gairah, merasa senang dan semangat untuk belajar. Dalam kegiatan belajar, motivasi dapat dikatakan sebagai daya penggerak didalam diri siswa yang menimbulkan kegiatan belajar, yang menjamin keberlangsungan dan memberikan arah kegiatan belajar sehingga tercapai tujuan belajar (Sardiman, 2011:75). Oleh karena itu, motivasi belajar siswa perlu diketahui untuk mengetahui pengaruhnya pada penggunaan pembelajaran kooperatif terhadap pencapaian pemahaman konsepdan pemecahan masalah. Dalam penelitian ini. Konteks pembelajaran pada kompetensi keahlian TKJ, sehingga motivasi belajar yang dimaksud adalah motivasi belajar TKJ (MBTKJ).

Permasalahan yang diteliti dalam penelitian ini yaitu bagaimana perbedaan pemahaman konsep dan pemecahan masalah pada materi KK3 antara siswa yang diajar dengan pembelajaran kooperatif tipe Jigsaw II dan siswa yang diajar dengan pembelajaran kooperatif tipe GI ketika motivasi belajar TKJ dikendalikan? Dengan rumusan tersebut, tujuan yang ingin dicapai dalam penelitian ini yaitu untuk mengetahui hasil pengujian perbedaan pemahaman konsep dan pemecahan masalah pada materi KK3 antara siswa yang diajar dengan pembelajaran kooperatif tipe Jigsaw II dan siswa yang diajar dengan pembelajaran kooperatif tipe GI ketika motivasi belajar TKJ dikendalikan.

\section{Materi KK3 pada pembelajaran produktif TKJ}

Materi KK3 merupakan salah satu materi pada pembelajaran produktif TKJ, yaitu materi pada Standar Kompetensi Mendiagnosis Permasalahan Pengoperasian PC dan Peripheral. Pembelajaran pada materi KK3 menitikberatkan pada penggunaan kemampuannya memilah informasi yang telah dipelajari pada materi sebelumnya yaitu materi merakit PC (DKK1) dan materi melakukan instalasi sistem operasi dasar (DKK2) untuk mendiagnosis permasalahan pengoperasian $\mathrm{PC}$ dan peripheral melalui pembelajaran praktikum.

\section{Pengaruh Motivasi Belajar TKJ}

Motivasi merupakan alasan seseorang berperilaku dan segala hal disekitarnya secara sengaja (Woolfolk (2007: 372; McLean (2009:7); Galton dkk (2009:9); Slavin (2009: 105); Mc Donald pada Hamalik (2011:106).) Apabila dilihat dari konteks pembelajaran maka motivasi merupakan sesuatu yang dapat 
menyebabkan siswa mau untuk belajar, membuat siswa untuk tetap belajar, dan menentukan apa yang ingin siswa pelajari. Kemudian ditambahkan juga bahwa motivasi belajar berpengaruh dalam pembelajaran karena merupakan daya penggerak dari diri siswa yang mendorong dalam kegiatan belajar dan menjaga keberlangsungan kegiatan belajar untuk mencapai tujuan belajar (Baharuddin \& Wahyuni (2007:22); Sardiman (2011:75); Djamarah (2008:148)). Sehingga terpapar dengan jelas bahwa motivasi belajar memiliki pengaruh besar dalam pencapaian tujuan belajar siswa. Dalam penelitian ini motivasi belajar yang dimaksud adalah motivasi belajar TKJ.

Disarikan dari McLean (2009:10), Galton, Steward, Hargreaves et al (2009:9), Jensen (2011:160), Reid (2009:19-23), Hamzah B. Uno (2008: 23), Hamalik (2009: 113), Santrock (2011:441), Woolfolk (2007:372377), Slavin (2011:102), Schunk, Pintrich \& Meece (2010:12), \& Sardiman.(2011:83), indikator untuk mengukur motivasi dalam penelitian ini adalah: (1) adanya hasrat dan keinginan diri untuk berhasil (self fulfillment); (2) adanya dorongan kebutuhan belajar (incentives); (3) memiliki harapan akan citacita (expectations); (4) adanya kebulatan tekad (self determination) yang bisa ditunjukkan dengan: (a) tekun menghadapi tugas; (b) tidak lekas putus asa; dan (c) memiliki tanggung jawab; (5) memiliki keyakinan (beliefs); (6) penguat (reinforces) yang dapat berupa : (a) kegiatan belajar yang menarik; dan (b) berhubungan dengan pengalaman (pengoptimalan dan berkelanjutan); (7) lingkungan belajar yang kondusif; (8) adanya penghargaan (rewards); dan (9) adanya hukuman (punishment).

\section{Langkah-langkah Pembelajaran Kooperatif Tipe Jigsaw II dan Tipe GI}

Langkah-langkah pembelajaran kooperatif secara umum yang terdiri dari 6 fase langkah pembelajaran, yaitu: (1) mengklasrifikasikan tujuan dan menata kelas; (2) mempresentasikan informasi; (3) mengorganisasikan siswa ke dalam tim-tim belajar; (4) membantu kerja tim dan belajar; (5) mengujikan berbagai materi; dan (6) memberikan pengakuan. Meskipun keenam fase langkah pembelajaran kooperatif secara umum tersebut dilakukan dalam kegiatan pembelajaran dalam penelitian ini, akan tetapi pada fase keempat untuk masing-masing tipe pembelajaran kooperatif memiliki perbedaan langkah pembelajaran. Langkah-langkah pembelajaran pada tipe Jigsaw II menurut Slavin (2009: 241) terdiri dari (1) membaca; (2) diskusi kelompok ahli; (3) laporan tim; (4) tes; dan (5) rekognisi tim. Sedangkan langkah-langkah pembelajaran pada tipe GI menurut Slavin (2009: 218-220) terdiri dari (1) mengidentifikasikan topik dan mengatur murid ke dalam kelompok; (2) merencanakan tugas yang akan dipelajari; (3) melaksanakan investigasi, (4) menyiapkan laporan akhir; (5) mempresentasikan laporan akhir; dan (6) evaluasi.Dilihat dari langkah-langkah pembelajaran kooperatif, terdapat perbedaan langkah-langkah pada fase keempat antara tipe Jigsaw II dan tipe GI yang berkaitan dengan adanya perbedaan upaya pengembangan pemahaman konsep pada kedua tipe tersebut.

\section{Pemahaman Konsep dalam Pembelajaran Kooperatif Tipe Jigsaw II dan Tipe GI}

Dalam Anderson \& Krathwohl (2010: 106), siswa memahami ketika mereka membangun hubungan antara pengetahuan baru dan pengetahuan lamanya. Dapat dikatakan bahwa pengetahuan awal yang sebelumnya diperoleh, mendorong tercapainya pemahaman konsep suatu materi. Dalam penguasaan materi KK3, siswa memerlukan pemahaman konsep mengenai materi kompetensi sebelumnya yang benar-benar diperlukan untuk mendiagnosis permasalahan pada materi KK3 sebagai upaya awal pemecahan masalah.

Konsep dapat diartikan sebagai penggambaran mengenai hubungan hal-hal yang memiliki karakteristik sama dan saling terkait yang apabila dikelompokkan dan diklasifikasikan bersama akan membentuk penjelasan mengenai suatu hal yang lebih umum (Woolfolk (2009:60); Jacobsen, Egen, \& Kauchak (2009:98); Chiappetta \& Koballa (2010:113); dan Nitko \& Brookhart (2011:225-230)). Sehingga pemahaman konsep dapat diartikan sebagai pemahaman terhadap sesuatu dengan cara membangun hubungan antara pengetahuan awal dan pengetahuan baru yang memiliki keterkaitan dari suatu pengkategorian dari beberapa hal yang sama.

Dalam ranah kognitif, pemahaman konsep (understanding) merupakan prasyarat mutlak untuk tingkatan kemampuan kognitif yang lebih tinggi. Kemampuan-kemampuan 
kognitif yang berbasis pemahaman melibatkan kemampuan berpikir seperti interpreting, exemplifying, classifying, summarizing, inferring, comparing dan explaining (Anderson \& Krathwohl (2001:66). Selain itu Santrock (2011: 295) menyatakan bahwa "complex cognitive process:understanding concepts, solving problems and transferring what they learn", dimana beberapa proses kognitif komplek terdiri dari pemahaman konsep, pemecahan masalah dan menyampaikan apa yang dipelajari. Jadi pemahaman konsep merupakan salah satu keterampilan berpikir dalam ranah kognitif.

Filosofi dari kurikulum dan pembelajaran kognitif yang menganjurkan pengalaman belajar diupayakan membantu siswa menemukan materi untuk mengembangkan keterampilan berfikirnya Dell'Olio \& Donk (2007:135), yang senada dengan pandangan konstruktivistik, bahwa pembelajaran bermakna dapat diwujudkan dengan menyediakan peluang bagi siswa untuk melakukan pemilihan terhadap informasi-informasi kemudian mengorganisasikan, dan mengintegrasikannya ke dalam pengetahuan awal dan pengalaman yang telah dimiliki. Sehingga keterampilan berfikir yang perlu dikembangkan adalah keterampilan pemahaman konsep "understanding" yaitu pemahaman terhadap sesuatu dengan cara membangun hubungan antara pengetahuan awal dan pengetahuan baru yang memiliki keterkaitan yang apabila dikelompokkan dan diklasifikasikan bersama akan membentuk penjelasan mengenai suatu hal yang lebih umum.

Slavin (2009: 215-246) menunjukkan bahwa Jigsaw II dan GI dapat mendukung pemahaman konsep dan pemecahan masalah. Dari beberapa penelitian relevan ditemukan hasil penelitian bahwa Jigsaw dan GI mampu mengembangkan pemahaman konsep siswa.

Upaya pengembangan pemahaman konsep pada pembelajaran kooperatif tipe Jigsaw II, terdapat pada langkah pembelajaran pertama, yaitu "membaca" dimana dalam kegiatan tersebut diperlukan kemampuan pemahaman konsep. Seperti disampaikan oleh Slavin (2009:245), bahwa kelebihan dari Jigsaw II adalah bahwa semua siswa membaca semua materi, yang akan membuat konsep-konsep yang telah disatukan menjadi lebih mudah dipahami. Sedangkan upaya pengembangan pemahaman konsep pada pembelajaran koo- peratif tipe GI, terdapat pada langkah pembelajaran "perencanaan investigasi", dimana dalam kegiatan tersebut diperlukan kemampuan pemahaman konsep. Seperti yang dipaparkan oleh Slavin (2009:222), pada tahap merencanakan investigasi, salah satu kegiatan yang dilakukan tiap kelompok adalah menentukan sumber-sumber mana yang akan dibutuhkan dalam investigasi.

\section{Pemecahan Masalah dalam Pembelajaran Kooperatif Tipe Jigsaw II dan Tipe GI}

Pemecahan masalah pada dasarnya kemampuan dan kecakapan kognitif untuk memecahkan masalah dengan memformulasikan sejumlah aturan, yang lebih dari sekedar penerapan sederhana dari aturan-aturan yang sudah dipelajari sebelumnya secara rasional, lugas dan tuntas, yang memerlukan kemampuan siswa dalam menguasai konsep-konsep, prinsip-prinsip dan generalisasi serta insight (tilikan akal) menggunakan metode ilmiah atau berpikir secara sistematis, logis, teratur dan teliti. (Agran (1997:172); Reardon (2001: 2); Syah (2003:127); Woolfolk (2007:295); Wena (2010:52); Santrock (2011:316). Sedangkan Nitko \& Brookhart (2011:231), menyatakan bahwa pemecahan masalah merupakan proses berpikir tingkat tinggi yang digunakan ketika siswa tidak dapat secara otomatis mengenali cara yang sesuai untuk mencapai tujuan. Selain itu Santrock (2011: 295) juga menyatakan bahwa beberapa proses kognitif komplek terdiri dari pemahaman konsep, pemecahan masalah dan menyampaikan apa yang dipelajari. Jadi pemecahan masalah merupakan salah satu keterampilan berpikir tingkat tinggi (higher order thinking) dalam ranah kognitif.

Pemecahan masalah memiliki keterkaitan erat dalam pencapaian tujuan materi KK3. Tujuan utama dari materi KK3 adalah ditemukan hasil diagnosis sebagai upaya pemecahan masalah dari adanya permasalahan PC dan Peripheral. Sehingga dalam pembelajaran materi KK3, masalah menjadi hal utama yang perlu dipecahkan. Dengan dasar tersebut, kemampuan pemecahan masalah memiliki tingkat kepentingan yang besar untuk dikembangkan oleh siswa dalam penguasaan materi KK3. 
Tabel 1. Perbandingan Dukungan Kajian Teoritis, Penelitian Relevan dan Tahapan Pembelajaran terhadap Pemahaman Konsep antara Tipe Jigsaw II dan GI

\begin{tabular}{|c|c|c|c|c|c|}
\hline \multicolumn{2}{|c|}{ Dukungan kajian teoritis } & \multicolumn{2}{|c|}{ Dukungan hasil penelitian relevan } & \multicolumn{2}{|c|}{$\begin{array}{c}\text { Kesesuaian tahapan } \\
\text { pembelajaran }\end{array}$} \\
\hline Jigsaw & GI & Jigsaw & GI & Jigsaw & GI \\
\hline \multirow{3}{*}{$\begin{array}{l}\text { Kelebihan dari } \\
\text { Jigsaw II adalah } \\
\text { bahwa semua } \\
\text { siswa membaca } \\
\text { semua materi, } \\
\text { yang akan } \\
\text { membuat } \\
\text { konsep-konsep } \\
\text { yang telah } \\
\text { disatukan } \\
\text { menjadi lebih } \\
\text { mudah dipahami } \\
\text { (Slavin, } \\
\text { 2009:245) }\end{array}$} & \multirow{3}{*}{$\begin{array}{l}\text { Pada tahap } \\
\text { merencanakan } \\
\text { investigasi, salah } \\
\text { satu kegiatan } \\
\text { yang dilakukan } \\
\text { tiap kelompok } \\
\text { adalah memahami } \\
\text { konsep-konsep } \\
\text { yang relevan atau } \\
\text { tidak untuk } \\
\text { dijadikan sumber } \\
\text { informasi dalam } \\
\text { investigasi (Slavin } \\
\text {, 2009:222) }\end{array}$} & \multirow{3}{*}{$\begin{array}{l}\text { Yani Nurhaeni } \\
(2011) \text {, } \\
\text { menunjukkan } \\
\text { bahwa Jigsaw } \\
\text { dapat } \\
\text { meningkatkan } \\
\text { pemahaman } \\
\text { konsep dan } \\
\text { pemecahan } \\
\text { masalah siswa }\end{array}$} & $\begin{array}{l}\text { 1.Lia Yuliana., } \\
\text { Sudiyon., } \\
\text { Meilina } \\
\text { Bustari., \& } \\
\text { Slamet } \\
\text { Lestari } \\
(2011)\end{array}$ & $\begin{array}{c}\text { Tahapan } \\
\text { pembelajaran } \\
\text { "membaca" } \\
\text { mendukung PK } \\
\text { hingga aspek } \\
\text { summarizing }\end{array}$ & $\begin{array}{c}\text { Tahapan } \\
\text { pembelajaran } \\
\text { "perencanaan } \\
\text { investigasi" } \\
\text { mendukung PK } \\
\text { hingga aspek } \\
\text { explaining }\end{array}$ \\
\hline & & & $\begin{array}{l}\text { 2.I Wayan } \\
\text { Santyasa } \\
(2009) \\
\text { menunjukkan } \\
\text { bahwa GI } \\
\text { menunjukkan } \\
\text { pemahaman } \\
\text { konsep }\end{array}$ & \multirow{2}{*}{\multicolumn{2}{|c|}{$\begin{array}{l}\text { - Explaining lebih tinggi dari } \\
\text { summarizing } \\
\text { - Pada Jigsaw, langkah } \\
\text { laporan tim untuk siswa yang } \\
\text { kurang pandai } \\
\text { berkomunikasi } \\
\text { dikhawatirkan mengganggu } \\
\text { proses transfer informasi } \\
\text { - Pada GI, langkah presentasi } \\
\text { menguatkan pemahaman }\end{array}$}} \\
\hline & & & & & \\
\hline
\end{tabular}

Tabel 2. Perbandingan Dukungan Kajian Teoritis, Penelitian Relevan dan Tahapan Pembelajaran terhadap Pemecahan Masalah antara Tipe Jigsaw II dan GI

\begin{tabular}{|c|c|c|c|c|}
\hline \multicolumn{2}{|c|}{ Dukungan kajian teoritis } & \multicolumn{2}{|c|}{ Dukungan hasil penelitian relevan } & $\begin{array}{l}\text { Kesesuaian tahapan } \\
\text { pembelajaran }\end{array}$ \\
\hline Jigsaw & GI & Jigsaw & GI & Jigsaw \\
\hline $\begin{array}{l}\text { Adanya diskusi } \\
\text { kelompok ahli, } \\
\text { dimana para } \\
\text { siswa dengan } \\
\text { keahlian yang } \\
\text { sama bertemu } \\
\text { untuk } \\
\text { mendiskusikanny }\end{array}$ & $\begin{array}{l}\text { GI sesuai untuk } \\
\text { proyek-proyek } \\
\text { studi yang } \\
\text { terintegrasi yang } \\
\text { berhubungan } \\
\text { dengan hal-hal } \\
\text { semacam } \\
\text { penguasaan, }\end{array}$ & $\begin{array}{l}\text { Yani Nurhaeni } \\
\text { (2011) } \\
\text { M. A. Hertiavi, } \\
\text { H. Langlang, } \\
\text { \& S. } \\
\text { Khanafiyah } \\
\text { (2010) }\end{array}$ & $\begin{array}{l}\text { 1. Nelsen } \\
\text { Pelealu } \\
(2013) \\
\text { 2. I Wayan } \\
\text { Santyasa } \\
\text { (2009), } \\
\text { ditunjukkan } \\
\text { bahwa GI }\end{array}$ & $\begin{array}{cc}\text { Tahapan } & \text { Tahapan } \\
\text { pembelajaran } & \text { pembelajaran } \\
\text { "diskusi } & \text { "pelaksanaan } \\
\text { kelompok" } & \text { investigasi" } \\
\text { mendukung PM } & \text { mendukung PM } \\
\text { aspek analysis } & \text { aspek identify, } \\
& \text { analysis, } \\
& \text { explore }\end{array}$ \\
\hline $\begin{array}{l}\text { a dalam } \\
\text { kelompok- } \\
\text { kelompok ahli } \\
\text { (Slavin, } \\
\text { 2009:241). } \\
\text { Diskusi sebagai } \\
\text { usaha pemecahan } \\
\text { masalah. }\end{array}$ & $\begin{array}{l}\text { analisis dan } \\
\text { mensintesiskan } \\
\text { informasi } \\
\text { sehubungan } \\
\text { dengan upaya } \\
\text { menyelesaikan } \\
\text { masalah yang } \\
\text { bersifat multi- } \\
\text { aspek (Slavin, } \\
\text { 2009:215-216) }\end{array}$ & $\begin{array}{l}\text { bahwa Jigsaw } \\
\text { dapat } \\
\text { meningkatkan } \\
\text { pemecahan } \\
\text { masalah siswa }\end{array}$ & $\begin{array}{l}\quad \text { lebih baik } \\
\quad \text { dari STAD } \\
\text { menunjukkan } \\
\text { bahwa GI dapat } \\
\text { meningkatkan } \\
\text { pemecahan } \\
\text { masalah siswa }\end{array}$ & $\begin{array}{ll}\text { - } & \text { Pada GI, langkah lebih } \\
\text { terstruktur }\end{array}$ \\
\hline
\end{tabular}

Slavin (2009:215-246) menunjukkan bahwa Jigsaw II dan GI dapat mendukung pemahaman konsep dan pemecahan masalah. Dari beberapa penelitian relevan ditemukan hasil penelitian bahwa Jigsaw dan GI mampu mengembangkan pemecahan masalah siswa.
Upaya pengembangan pemecahan masalah pada pembelajaran kooperatif tipe Jigsaw II, terdapat pada langkah pembelajaran kedua, yaitu "diskusi kelompok ahli" dimana dalam kegiatan tersebut diperlukan kemampuan pemecahan masalah karena dalam langkah 
pembelajaran tersebut siswa dituntut untuk saling memberikan pendapat mengenai upaya pemecahan masalah dari permasalahan PC dan peripheral yang sudah di-setting oleh guru. Seperti disampaikan oleh Slavin (2009: 241), pada Jigsaw II terdapat diskusi kelompok ahli, dimana para siswa dengan keahlian yang sama bertemu untuk mendiskusikannya dalam kelompok-kelompok ahli. Atau dengan kata lain pada pelaksanaan diskusi kelompok ahli, upaya pemecahan masalah dilakukan dengan diskusi bersama. Sedangkan upaya pengembangan pemecahan masalah pada pembelajaran kooperatif tipe GI, terdapat pada langkah pembelajaran "pelaksanaan investigasi", dimana dalam kegiatan tersebut diperlukan kemampuan pemecahan masalah. Seperti yang dipaparkan oleh Slavin (2009:215-216), GI sesuai untuk proyek-proyek studi yang terintegrasi yang berhubungan dengan hal-hal semacam penguasaan, analisis dan mensintesiskan informasi sehubungan dengan upaya menyelesaikan masalah yang bersifat multiaspek.

Tabel 1 dan 2 menunjukkan dukungan pemahaman konsep dan pemecahan masalah pada pembelajaran kooperatif tipe Jigsaw II dan tipe GI.

\section{METODE PENELITIAN}

\section{Jenis Penelitian}

Penelitian ini merupakan penelitian kuasi eksperimen (quasi experimental research). Dalam penelitian ini tidak memberikan kontrol penuh. Alasan utama mengapa kontrol penuh tidak tercapai karena di dalam penelitian ini tidak dilakukan pemilihan subjek dalam suatu kelompok secara acak (Johnson \& Christensen, 2008:328). Gall, Gall
\& Borg (2007:398 \& 401) menyatakan bahwa memilih subjek secara acak hampir tidak dimungkinkan dilakukan pada penelitian bidang pendidikan.

\section{Waktu dan Tempat Penelitian}

Penelitian dilaksanakan di SMK 1 Sedayu yang beralamat di Argomulyo, Pos Kemusuk, Bantul, Yogyakarta 55753. Waktu yang digunakan untuk melaksanakan penelitian ini adalah semester ganjil tahun ajaran 2012/2013. Pengambilan data penelitian pada bulan Oktober 2012 sampai dengan bulan Desember 2012.

\section{Populasi dan Sampel Penelitian}

Populasi Penelitian dalam penelitian ini adalah seluruh siswa kelas $\mathrm{X}$ TKJ Tahun Ajaran 2012/2013. Pengambilan sampel dilakukan dengan teknik purposive sampling. Ini dilakukan karena pengambilan sampel dari populasi dengan melakukan berbagai pertimbangan tertentu (Sugiyono, 2007: 68). Menurut Nasution (2003), pengambilan sampel dengan purposive sampling dilakukan atas dasar pertimbangan peneliti dengan unsurunsur yang dikehendaki telah ada dalam sampel. Unsur-unsur tersebut disesuaikan dengan kerangka sampling (sampling frame). Dari Asropi (2008), sampling frame merupakan suatu daftar yang dapat menggambarkan seluruh elemen dari populasi. Pengambilan sampel dilakukan oleh peneliti karena sampel telah memenuhi unsur-unsur yang sesuai dengan penelitian ini. Sampel terdiri dari dua kelas yang akan mendapatkan dua perlakuan pembelajaran kooperatif dengan tipe berbeda. Sampel tersebut ialah kelas XTKJA dan kelas XTKJB SMK 1 Sedayu. Berikut ini adalah sampling frame dari sampel yang diharapkan

Tabel 3. Sampling Frame XTKJ SMK 1 Sedayu dan antara Kelas XTKJA-XTKJB

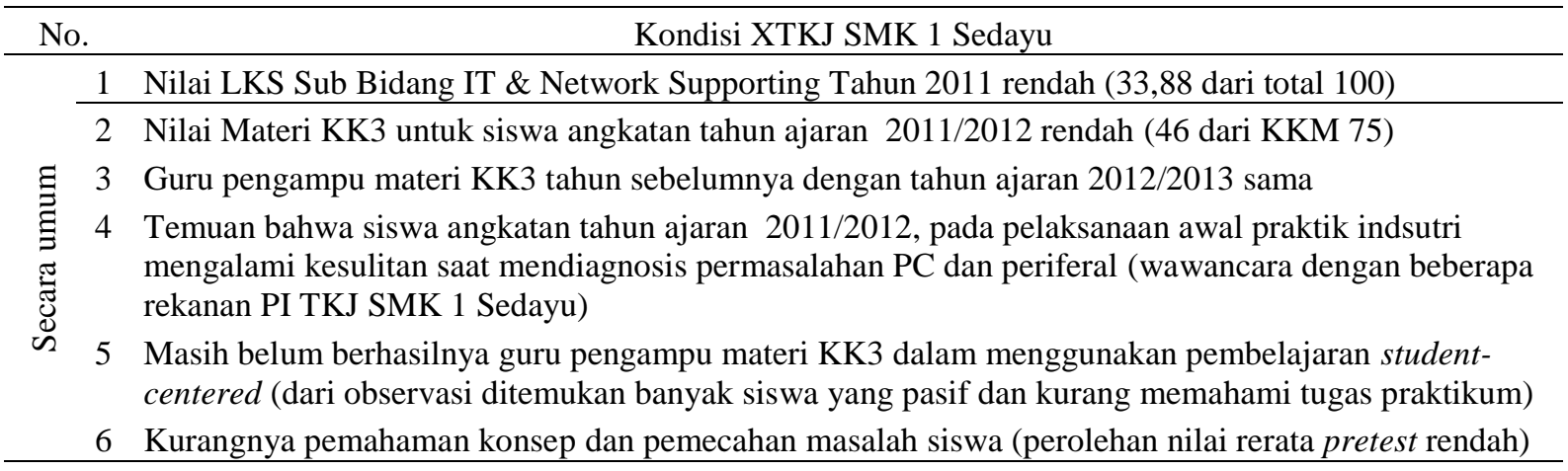




\begin{tabular}{|c|c|c|c|c|}
\hline \multicolumn{2}{|c|}{ No. } & Kondisi & $\begin{array}{r}\text { Kelas } \\
\text { XKJA } \\
\end{array}$ & $\begin{array}{l}\text { Kelas } \\
\text { XKJB }\end{array}$ \\
\hline \multirow{7}{*}{ 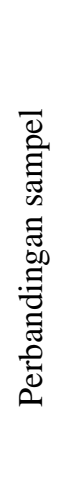 } & 1 & $\begin{array}{l}\text { Pendistribusian siswa di tiap kelas dilakukan berdasarkan perolehan skor } \\
\text { Penerimaan Peseta Didik Baru (PPDB) cukup merata. }\end{array}$ & $\sqrt{ }$ & $\sqrt{ }$ \\
\hline & 2 & Pembagian kelompok jenis kelamin diantara kedua kelas yang cukup merata. & $\begin{array}{l}14 \text { siswi, } \\
18 \text { siswa }\end{array}$ & $\begin{array}{l}15 \text { siswi, } \\
18 \text { siswa }\end{array}$ \\
\hline & 3 & Sswa dalam satu kelas berjumlah lebih dari 30 siswa & 32 siswa & 33 siswa \\
\hline & 4 & Kedua kelas diajar oleh guru yang sama & $\sqrt{ }$ & $\sqrt{ }$ \\
\hline & 5 & $\begin{array}{l}\text { Kedua kelas pernah melakukan kegiatan praktikum berkelompok (diskusi dan } \\
\text { kerjasama) }\end{array}$ & $\sqrt{ }$ & $\sqrt{ }$ \\
\hline & 6 & $\begin{array}{l}\text { Kedua kelas pernah mendapatkan materi Merakit PC dan Melakukan Instalasi } \\
\text { Sistem Operasi Dasar }\end{array}$ & $\sqrt{ }$ & $\sqrt{ }$ \\
\hline & 7 & Kedua kelas, materi dimulai pada waktu yang sama (pagi hari) & $\sqrt{ }$ & $\sqrt{ }$ \\
\hline
\end{tabular}

\section{Prosedur}

Desain penelitian ini menggunakan desain pretest-postest dengan kelompok nonekuivalen (nonequivalent comparison-group design). Adapun desain penelitan yang digunakan ditunjukkan dalam tabel berikut.

Tabel 4. Desain Penelitian
Keterangan:

$\mathrm{KE}_{1} \quad$ : Kelas Eksperimen 1

$\mathrm{KE}_{2}$ : Kelas Eksperimen 2

$\mathrm{O}_{1} \quad$ : Pretest dan pengisian angket MBTKJ

$\mathrm{O}_{2} \quad$ : Posttest

$\mathrm{X}_{1}$ : Tipe Jigsaw II

$\mathrm{X}_{2}$ : Tipe $\mathrm{G}$

\begin{tabular}{cccc}
\hline Kelompok & Pretest & Perlakuan & Posttest \\
\hline $\mathrm{KE}_{1}$ & $\mathrm{O}_{1}$ & $\mathrm{X}_{1}$ & $\mathrm{O}_{2}$ \\
$\mathrm{KE}_{2}$ & $\mathrm{O}_{1}$ & $\mathrm{X}_{2}$ & $\mathrm{O}_{2}$ \\
\hline
\end{tabular}

Tabel 5. Kontrol Treatment

\begin{tabular}{|c|c|c|}
\hline No. & Kontrol & Keterangan \\
\hline \multirow[t]{4}{*}{1} & \multirow{4}{*}{$\begin{array}{l}\text { Unsur peristiwa dari } \\
\text { proses pembelajaran } \\
\text { (history) }\end{array}$} & $\begin{array}{l}\text { dimulai pagi hari (tidak merubah jadwal saat melakukan } \\
\text { proses pembelajaran) }\end{array}$ \\
\hline & & sama untuk kedua kelas eksperimen \\
\hline & & $\begin{array}{l}\text { Kelas (Teori), Bengkel Perbaikan PC dan Periferal } \\
\text { (Praktikum) }\end{array}$ \\
\hline & & Selalu melakukan presensi kehadiran siswa. \\
\hline 2 & $\begin{array}{l}\text { Unsur maturasi } \\
\text { (maturation) }\end{array}$ & $\begin{array}{l}\text { Siswa sudah terbiasa melakukan pembelajaran produktif bahkan hingga8 jam } \\
\text { pelajaran untuk satu materi. }\end{array}$ \\
\hline 3 & $\begin{array}{l}\text { Pengaruh pemberian } \\
\text { tes } \\
\text { (testing) }\end{array}$ & $\begin{array}{l}\text { Tes pilihan ganda yang digunakan baik untuk pretest maupun posttest dan } \\
\text { kuis/evaluasi yang dilakukan diakhir perlakuan sama untuk kedua kelas, } \\
\text { dimana posttest berbeda dengan pretest tetapi memiliki kesamaan karakteristik } \\
\text { yang mengukur indikator yang sama }\end{array}$ \\
\hline 4 & $\begin{array}{l}\text { Unsur instrument } \\
\text { (instrumentation) }\end{array}$ & $\begin{array}{l}\text { Materi sama : materi KK3(disesuaikan dengan standar isi pendidikan saat ini } \\
\text { dan metode pembelajaran disesuaikan dengan panduan pembelajaran } \\
\text { kooperatif tipe Jigsaw II dan GI) }\end{array}$ \\
\hline 5 & $\begin{array}{l}\text { Unsur subjek } \\
\text { penelitian }\end{array}$ & $\begin{array}{l}\text { Memenuhi uji homogenitas dan uji kesamaan rerata melalui nilai pretest, serta } \\
\text { pemilihan tipe pembelajaran kooperatif dengan undian. }\end{array}$ \\
\hline & $\begin{array}{l}\text { (statistical } \\
\text { regression) }\end{array}$ & $\begin{array}{l}\text { Pelaksanaan kuis/evaluasi, pretest dan posttest dilakukan dengan penjagaan } \\
\text { yang baik. }\end{array}$ \\
\hline
\end{tabular}


Kedua kelompok eksperimen diberi tahapan perlakuan sama yaitu pertama diberi pretest dan pengisian angket MBTKJ, kemudian diberi pembelajaran materi $\mathrm{KK} 3$, dan terakhir diberi posttest. Dalam memberikan pembelajaran, kedua kelompok mendapatkan perlakuan yaitu pembelajaran materi KK3 dengan pembelajaran kooperatif tipe Jigsaw II dan tipe GI. Pretest untuk melihat kondisi awal siswa kedua kelompok eksperimen tersebut tidak berbeda secara signifikan sebelum diberikan perlakuan baik terhadap pemahaman konsep dan pemecahan masalah siswa. Pengisian angket MBTKJ bertujuan untuk diukur sebagai kovarian. Sedangkan posttes digunakan untuk melihat pemahaman konsep dan pemecahan masalah setelah diberi perlakuan.

Untuk melihat kebenaran hasil perbedaan dari dua kelas yang diteliti tersebut, maka terdapat beberapa hal yang perlu dikontrol terkait untuk menjaga validitas internal. Menurut Johnson \& Christensen (2008:329), untuk nonequivalent comparison-group design beberapa hal yang perlu di kendalikan yaitu terdiri dari history, maturation, testing, instrumentation dan regression artifact. Berdasarkan penjabaran dari Wiersma (1995:114) mengenai kelima hal untuk menjaga validitas internal tersebut, table berikut ini adalah berisi hal yang dilakukan dalam penelitian ini.

\section{Data, Intrumen, dan Teknik Pengumpulan Data}

Dalam penelitian ini, data primer diperoleh langsung oleh peneliti dengan memberikan perlakuan kepada kedua kelas eksperimen. Teknik pengumpulan data yang dimaksud adalah cara-cara atau tahapan yang dilalui dalam pengumpulan data. Teknik pengumpulan data dilakukan dengan dua cara yaitu: (1) teknik tes pilihan ganda terdiri dari pretest dan posttest untuk mengukur pemahaman konsep dan pemecahan masalah; dan (2) teknik non tes berupa angket untuk mengukur motivasi belajat TKJ siswa.

Teknik penilaian tersebut berdasarkan bahwa: (1) bahwa untuk mengukur pemahaman konsep dapat digunakan teknik background knowledge probe dan misconception/ preconception check menggunakan tes pilihan ganda (Angelo \& Cross (1993:119-158); dan Stiggins \& Chappuis (2012:77-80)); (2) untuk mengukur pemecahan masalah dapat diguna- kan teknik whats the principle? dalam hal ini siswa mampu menentukan jawaban yang tepat dari beberapa pilihan jawaban (pilihan ganda) pada soal yang diberikan (Sumarna Surapranata (2005:137) dan Angelo \& Cross (1993: 213-230)); dan (3) untuk mengukur motivasi belajar dapat digunakan Instrumen self reports misalnya angket tertutup dengan empat skala (Schunk, Pintrich \& Meece (2010:13-17), Sukandarrumidi (2006:79) dan Djemari Mardapi (2008:121)).

Pada proses pelaksanaan pengumpulan data penelitian, terdapat langkah-langkah yang ditempuh oleh peneliti, yaitu:

a. Pengundian kelas untuk menentukan kelas yang akan diberi perlakuan pembelajaran Jigsaw II dan kelas yang akan diberi perlakuan pembelajaran GI.

b. Pengerjaan pretest dan angket oleh tiap siswa, dimana pretest untuk ada tidaknya perbedaan rerata kedua kelas dan angket untuk mengetahui motivasi belajar TKJ siswa.

c. Pemberian Perlakuan untuk kedua kelas perlakuan. Masing-masing pembelajaran tersebut disesuaikan dengan RPP yang telah dibuat, sebagai kontrol pelaksanaan langkah pembelajaran kooperatif baik tipe Jigsaw II maupun tipe GI.

d. Pengerjaan posttest oleh siswa kelompok eksperimen 1 (Jigsaw II) dan 2 (GI) untuk mengetahui kemampuan pema-haman konsep dan pemecahan masalah setelah diberi perlakuan.

\section{Teknik Analisis Data}

Menurut Cook \& Campbell (1979: 149), analisis yang bisa digunakan dalam desain penelitian kelompok non ekuivalen diantaranya analysis of variance, analysis of variance, analysis of variance with blocking or matching dan analysis of variance with gain scores. Analisis data menggunakan desain faktorial dengan analisis multivarian anova.

Tabel 6. Desain Faktorial 2 x 2 untuk Masing-Masing Variabel Dependen

\begin{tabular}{ccc}
\hline \multirow{2}{*}{$\begin{array}{c}\text { Motivasi Belajar TKJ } \\
\text { (MBTKJ) }\end{array}$} & \multicolumn{2}{c}{ Tipe Pembelajaran } \\
\cline { 2 - 3 } & Jigsaw (JG) & GI \\
\hline MBTKJ Tinggi (MT) & JGMT & GIMT \\
MBTKJ Rendah (MR) & JGMR & GIMR \\
\hline
\end{tabular}


Keterangan:

JGMT: rerata variabel terikat (PK atau PM) siswa dengan pembelajaran Jigsaw II yang memiliki motivasi belajar TKJ tinggi

JGMR: rerata variabel terikat (PK atau PM) siswa dengan pembelajaran Jigsaw II yang memiliki motivasi belajar TKJ rendah

GIMT: rerata variabel terikat (PK atau PM) siswa dengan pembelajaran GI yang memiliki motivasi belajar TKJ tinggi

GIMR: rerata variabel terikat (PK atau PM) siswa dengan pembelajaran GI yang memiliki motivasi belajar TKJ rendah

Analisis data yang dilakukan dalam penelitian ini adalah: (1) uji prasyarat analisis data pretest, motivasi belajar dan posttest; (2) uji perbedaan nilai rerata pretest dan posttest; (3) uji hipotesis menggunakan multivariat analysis of variances.

\section{HASIL PENELITIAN DAN PEMBAHASAN}

Sebelum melakukan uji hipotesis harus dilakukan uji prasyarat terlebih dahulu. Berikut ini adalah ringkasan hasil uji prasyarat data sebelum dan setelah treatment, yang menunjukkan bahwa data memenuhi prasyarat analisis.

Tabel 7. Ringkasan hasil uji prasyarat data sebelum dan setelah treatment

\begin{tabular}{cc}
\hline Data & Keputusan \\
Prasyarat analisis (normalitas dan homogenitas) \\
Pretest & Normal dan homogen \\
Motivasi & Normal dan homogen \\
belajar & Normal dan homogen \\
Posttest & Perbedaan rerata \\
& Tidak terdapat perbedaan \\
Pretest & Terdapat perbedaan \\
Posttest &
\end{tabular}

Setelah berbagai uji prasyarat analisis, selanjutnya dilakukan uji hipotesis. Hasil perhitungan ditunjukkan melalui tabel 8 .

Tabel 8. Ringkasan Hasil Uji Pengaruh Perbedaan Penggunaan Tipe Pembelajaran Kooperatif dengan Kategori MBTKJ terhadap Pemahaman Konsep dan Pemecahan Masalah

\begin{tabular}{ccccccc}
\hline Sumber varians & Var. & $\mathrm{F}_{\text {hitung }}$ & $\mathrm{F}_{\text {tabel }}$ & $(1,61)$ & Sig. & Keputusan uji \\
\hline Interaksi antara Tipe Kooperatif & PK & 0,223 & 4,00 & 0,638 & Tidak terdapat interaksi \\
dengan Kategori MBTKJ & PM & 0,361 & 4,00 & 0,550 & Tidak terdapat interaksi \\
& PK & 9,982 & 4,00 & 0,002 & Terdapat perbedaan \\
Tipe Kooperatif (Jigsaw II dan GI) & PM & 25,46 & 4,00 & 0,000 & Terdapat perbedaan \\
& PK & 8,014 & 4,00 & 0,006 & Terdapat perbedaan \\
Kategori MBTKJ (tinggi dan rendah) & PM & 19,53 & 4,00 & 0,000 & Terdapat perbedaan \\
\hline
\end{tabular}

Keterangan: Var $=$ Variabel Terikat;

$\mathrm{PK}=$ Pemahaman Konsep;

$\mathrm{PM}=$ Pemecahan Masalah;

MBTKJ= Motivasi Belajar TKJ

Beberapa hal yang bisa disimpulkan dari tabel di atas, dapat dinyatakan seperti berikut.

a) Pada baris interaksi antara tipe kooperatif dan kategori MBTKJ diketahui bahwa: (1) nilai signifikansi pada kedua variabel terikat $>0,05$; dan (2) nilai $\mathrm{F}_{\text {hitung }}<\mathrm{F}_{\text {tabel }}$, maka $\mathrm{H} 0$ diterima sehingga tidak terdapat interaksi antara penggunaan tipe pembelajaran kooperatif dengan kategori motivasi belajar TKJ terhadap pemahaman konsep dan pemecahan masalah. Berikut ini adalah gambar yang menunjukkan bahwa tidak terdapat interaksi yang signifikan. 


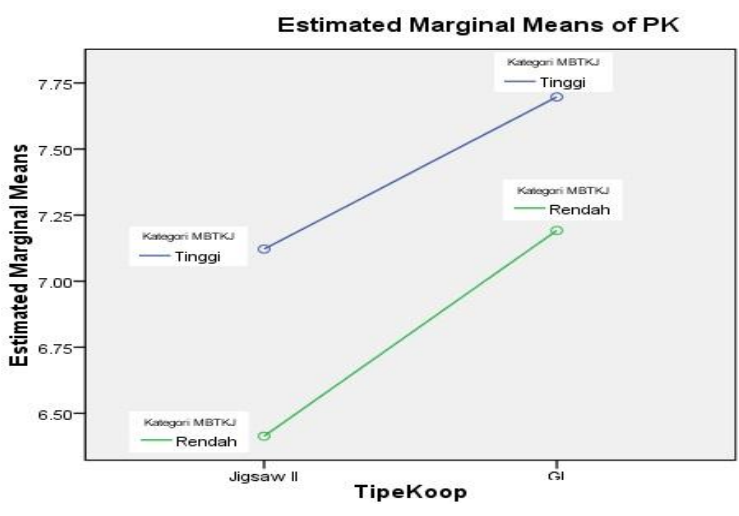

Gambar 1. Interaksi Pembelajaran Kooperatif dengan Motivasi Belajar TKJ pada Pemahaman Konsep

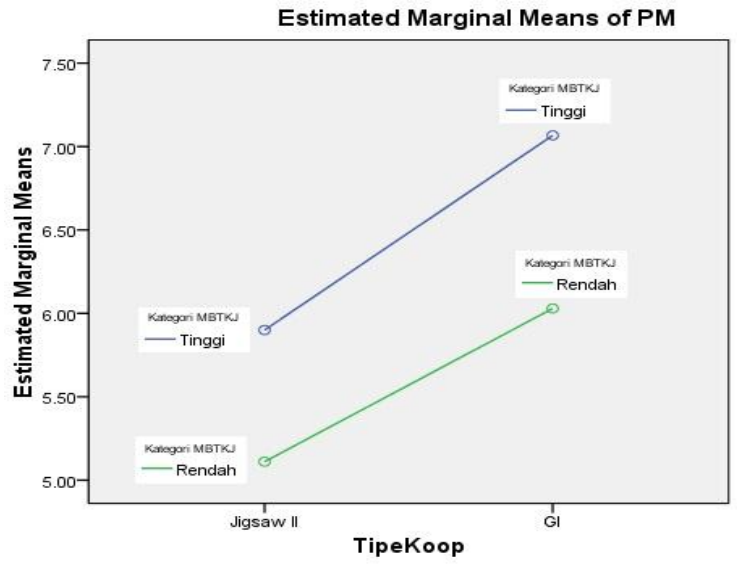

Gambar 2. Interaksi Pembelajaran Kooperatif dengan Motivasi Belajar TKJ pada Pemecahan Masalah b) Pada baris tipe kooperatif diketahui bahwa: (1) nilai signifikansi pada kedua variabel terikat $<0,05$; dan (2) nilai $F_{\text {hitung }}$ $>\mathrm{F}_{\text {tabel}}$, maka $\mathrm{H} 0$ ditolak sehingga terdapat perbedaan pemahaman konsep dan pemecahan masalah pada materi KK3 antara penggunaan tipe pembelajaran kooperatif tipe Jigsaw II dan tipe GI.

c) Pada baris kategori MBTKJ diketahui bahwa: (1) nilai signifikansi pada kedua variabel terikat $<0,05$; dan (2) nilai $\mathrm{F}_{\text {hitung }}$ $>\mathrm{F}$ tabel, maka $\mathrm{H} 0$ ditolak sehingga terdapat perbedaan pemahaman konsep dan pemecahan masalah pada materi KK3 antara motivasi belajar TKJ tinggi dan rendah.

Dari hasil uji tersebut ditemukan bahwa tidak terdapat interaksi antara tipe pembelajaran kooperatif dengan kategori motivasi belajar TKJ, akan tetapi ditemukan bahwa terdapat perbedaan pemahaman konsep dan pemecahan masalah pada materi KK3 baik antara perbedaan tipe pembelajaran kooperatif maupun perbedaan kategori MBTKJ. Oleh karena itu selanjutnya perlu dibahas mengenai mana saja yang berbeda dan mana saja yang tidak berbeda menggunakan uji Scheffe pada Post Hoc seperti berikut ini.

Tabel 9. Ringkasan Hasil Uji Perbedaan Pemahaman Konsep dan Pemecahan Masalah ditinjau dari Variabel Pengelompokkan

\begin{tabular}{|c|c|c|c|c|c|}
\hline \multirow{2}{*}{ Variabel } & \multicolumn{2}{|c|}{ Kelompok yang dibandingkan } & \multirow{2}{*}{$\begin{array}{l}\text { Beda rerata } \\
(\mathrm{I}-\mathrm{J})\end{array}$} & \multirow{2}{*}{ Sig. } & \multirow{2}{*}{ Keputusan uji } \\
\hline & Kelompok 1 (I) & Kelompok $2(\mathrm{~J})$ & & & \\
\hline \multirow{4}{*}{ 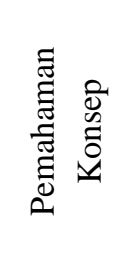 } & JGMT: 7,121 & JGMR: 6,413 & 0,708 & 0,098 & tidak terdapat perbedaan \\
\hline & GIMT: 7,697 & GIMR: 7,192 & 0,506 & 0,355 & tidak terdapat perbedaan \\
\hline & JGMT: 7,121 & GIMT: 7,697 & 0,576 & 0,269 & tidak terdapat perbedaan \\
\hline & GIMR: 7,192 & JGMR: 6,413 & 0,778 & 0,046 & terdapat perbedaan \\
\hline \multirow{4}{*}{ 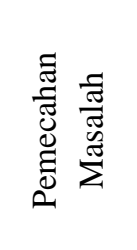 } & JGMT: 5,900 & JGMR: 5,111 & 0,789 & 0,041 & terdapat perbedaan \\
\hline & GIMT: 7,067 & GIMR: 6,029 & 1,037 & 0,004 & terdapat perbedaan \\
\hline & JGMT: 5,900 & GIMT: 7,067 & 1,167 & 0,002 & terdapat perbedaan \\
\hline & GIMR: 6,029 & JGMR: 5,111 & 0,918 & 0,009 & terdapat perbedaan \\
\hline
\end{tabular}

Keterangan: JG = Jigsaw II; GI= Group Investigation; $\mathrm{MT}=$ MBTKJ tinggi dan MR = MBTKJ rendah 
Beberapa hal yang bisa disimpulkan dari tabel di atas, dapat dinyatakan seperti berikut.

\section{Pemahaman konsep}

Untuk pencapaian pemahaman konsep, pembelajaran kooperatif tipe Jigsaw II dan tipe GI baik diaplikasikan untuk siswa yang memiliki motivasi belajar TKJ tinggi, akan tetapi untuk siswa yang memiliki motivasi belajar TKJ rendah lebih baik menggunakan tipe GI ( $\overline{\mathrm{X}}$ JGMT $=7,121 ; \overline{\mathrm{X}} \mathrm{JGMR}=6,413$; $\overline{\mathrm{X}} \mathrm{GIMT}=7,697$; dan $\overline{\mathrm{X}} \mathrm{GIMR}=7,192$ ).

Untuk pengembangan pemahaman konsep, pembelajaran kooperatif tipe Jigsaw II dan tipe GI baik diaplikasikan untuk siswa yang memiliki motivasi belajar TKJ tinggi. Temuan empirik tersebut sejalan dengan kajian teoritis yang menyatakan bahwa cooperative learning adalah model yang unik di antara model-model pembelajaran lainnya karena salah satunya menggunakan struktur hadiah atau reward untuk mendukung pembelajaran siswa (Arends, 2008: 5), dimana hadiah atau reward itu merupakan penghargaan yang termasuk upaya meningkatkan motivasi khususnya motivasi ekstrinsik (Reid, 2009:19-23). Sehingga dalam kedua tipe pembelajaran kooperatif tersebut upaya peningkatan motivasi ekstrinsik dalam struktur reward tersebut dinilai mampu mendukung upaya pengembangan pemahaman konsep baik di kelas Jigsaw II maupun GI bagi siswa yang memiliki motivasi belajar TKJ tinggi. Siswa yang memiliki motivasi belajar TKJ tinggi dan rendah di kelas GI dapat bekerja sama dengan baik mengoptimalkan pembelajaran. Siswa yang memiliki motivasi belajar TKJ tinggi di Jigsaw II dinilai cukup mampu dalam memberikan transfer informasi, sehingga terdapat beberapa rincian hipotesis penelitian yang tidak terbukti. Dikelas Jigsaw II proses transfer informasi bisa dikatakan berhasil, dengan tidak adanya siswa di kelas Jigsaw II yang minder saat berperan sebagai ahli dalam kelompoknya untuk menyampaikan apa yang telah dipelajari sebelumnya pada diskusi kelompok ahli. Bahkan, tahap pengembangan pemahaman konsep yang terjadi di kelas Jigsaw II pada beberapa kelompok (dengan peran siswa ahli oleh siswa yang diketahui memiliki MBTKJ tinggi dan memiliki kemampuan yang lebih dari siswa lainnya) terlihat hingga tahap explaining (sama dengan pencapaian tahap pengembangan pemahaman konsep di kelas GI).

Dengan kata lain bagi siswa yang memiliki motivasi belajar TKJ tinggi dan rendah pada baik Jigsaw II maupun GI memiliki andil yang sama baiknya terhadap pencapaian pemahaman konsep karena dengan perbedaan motivasi tersebut cukup mampu bersinergi dengan pengoptimalan pelaksanaan langkahlangkah pembelajaran kooperatif tipe Jigsaw II atau GI. Dimana adanya unsur reward untuk kelompok yang berprestasi secara nyata mampu menjadi penggerak siswa yang memiliki motivasi belajar TKJ tinggi dan rendah untuk bekerja sama dan saling membantu dalam pencapaian pemahaman konsep, dalam hal ini kontribusi pribadi tiap siswa memiiki pengaruh terhadap perolehan kelompok.

Hasil temuan empirik lainnya yang menyatakan bahwa untuk siswa yang memiliki motivasi belajar TKJ rendah lebih baik menggunakan tipe GI. Temuan empirik tersebut sejalan dengan paparan kajian teoritis sebelumnya yang pada dasarnya upaya peningkatan motivasi ekstrinsik dalam struktur reward di kedua tipe pembelajaran kooperatif tersebut dinilai mampu mendukung upaya pengembangan pemahaman konsep, meskipun demikian ternyata di GI didapatkan kajian teoritis bahwa dengan mengundang siswa untuk menghubungkan masalah-masalah yang akan mereka selidiki berdasarkan keingintahuan, pengetahuan dan perasaan mereka, GI mempertinggi minat pribadi mereka untuk mencari informasi yang diperlukan (Sharan, 2012: 172), sehingga diketahui bahwa dalam GI tidak hanya motivasi ekstrinsik yang diupayakan dalam proses pembelajaran, melainkan motivasi intrinsik juga diupayakan dalam proses pembelajaran GI. Seperti yang dinyatakan Reid (2009:19), bahwa idealnya motivasi haruslah intrinsik, yakni pembelajar memiliki motivasi diri (self motivating). Adanya motivasi intrinsik dalam pembelajaran kooperatif tipe GI merupakan penyebab bahwa secara empirik tipe GI mampu memberikan pengembangan pemahaman konsep yang lebih baik dari tipe Jigsaw II.

Bagi siswa yang memiliki motivasi belajar TKJ tinggi antara dikelas dengan penggunaan pembelajaran kooperatif tipe Jigsaw II dan GI memiliki andil yang sama baiknya terhadap pencapaian pemahaman 
konsep karena dengan motivasi tinggi yang dimiliki tersebut cukup mampu bersinergi dengan pengoptimalan pelaksanaan langkahlangkah pembelajaran kooperatif tipe Jigsaw II atau GI. Adanya motivasi intrinsik dalam GI dan adanya asumsi bahwa siswa yang memiliki motivasi belajar TKJ rendah kurang bisa melakukan transfer informasi saat siswa tersebut berperan sebagai expert dalam kelompoknya menjadi alasan utama adanya temuan bahwa siswa yang memiliki motivasi belajar TKJ rendah lebih baik menggunakan tipe GI.

\section{Pemecahan masalah}

Untuk pencapaian pemecahan masalah, pembelajaran kooperatif tipe Jigsaw II dan tipe GI baik diaplikasikan untuk siswa yang memiliki motivasi belajar TKJ tinggi, dimana siswa yang memiliki motivasi belajar TKJ rendah maupun siswa yang memiliki motivasi belajar TKJ tinggi lebih baik menggunakan tipe GI ( $\overline{\mathrm{X}} \mathrm{JGMT}=5,900 ; \overline{\mathrm{X}} \mathrm{JGMR}=5,111$; $\overline{\mathrm{X}} \mathrm{GIMT}=7,067$; dan $\overline{\mathrm{X}}$ GIMR $=6,029$ ).

Untuk pengembangan pemecahan masalah, pembelajaran kooperatif tipe Jigsaw II dan tipe GI baik diaplikasikan untuk siswa yang memiliki motivasi belajar TKJ tinggi, dimana siswa yang memiliki motivasi belajar TKJ rendah maupun siswa yang memiliki motivasi belajar TKJ tinggi lebih baik menggunakan tipe GI. Dari hasil tersebut diketahui bahwa perbedaan tipe pembelajaran kooperatif bagi siswa yang memiliki motivasi belajar TKJ tinggi dan rendah memiliki perbedaan terhadap pemecahan masalah siswa. Temuan empirik tersebut sejalan dengan kajian teoritis yang menyatakan bahwa pemecahan masalah pada dasarnya kemampuan dan kecakapan kognitif untuk memecahkan masalah dengan memformulasikan sejumlah aturan, yang lebih dari sekedar penerapan sederhana dari aturan-aturan yang sudah dipelajari sebelumnya secara rasional, lugas dan tuntas, yang memerlukan kemampuan siswa dalam menguasai konsep-konsep, prinsip-prinsip dan generalisasi serta insight (tilikan akal) menggunakan metode ilmiah atau berpikir secara sistematis, logis, teratur dan teliti. (Agran (1997:172); Reardon (2001:2); Muhibbin Syah, 2003:127; Woolfolk (2007:295); Made Wena (2010:52; Santrock (2011:316). Hal tersebut menyiratkan bahwa pemecahan masalah membutuhkan proses berpikir yang tinggi dan lebih dari penguasaan konsep yang membutuhkan prosedur-prosedur sistematis, sehingga membutuhkan daya penggerak belajar yang tidak sekedar ada tetapi bahkan tinggi agar tidak berhenti di tempat ketika siswa mengalami hambatan pada tahapan-tahapan awal pemecahan masalah, dimana daya penggerak tersebut ialah motivasi belajar TKJ yang tinggi. Selain itu juga diperlukan suatu kegiatan belajar yang secara sistematis memiliki karakteristik yang sama dengan karakteristik tahapan pemecahan masalah agar siswa secara tidak langsung belajar memahami tahapan pemecahan masalah yang memudahkannya memecahkan masalah, dimana kegiatan belajar tersebut adalah kegiatan belajar dengan pembelajaran GI.

\section{SIMPULAN DAN SARAN}

\section{Simpulan}

Berdasarkan data dan hasil pembahasan, dapat disimpulkan bahwa: (1) Untuk pencapaian pemahaman konsep, pembelajaran kooperatif tipe Jigsaw II dan tipe GI baik diaplikasikan untuk siswa yang memiliki motivasi belajar TKJ tinggi dan rendah, akan tetapi untuk siswa yang memiliki motivasi belajar TKJ rendah lebih baik menggunakan tipe GI dan (2) Untuk pencapaian pemecahan masalah, pembelajaran kooperatif tipe Jigsaw II dan tipe GI baik diaplikasikan untuk siswa yang memiliki motivasi belajar TKJ tinggi, siswa yang memiliki motivasi belajar TKJ rendah maupun siswa yang memiliki motivasi belajar TKJ tinggi lebih baik menggunakan tipe GI.

Saran

Berdasarkan hasil penelitian dan simpulan, implikasi hasil penelitian ini adalah sebagai berikut.

1. Pemahaman konsep dan pemecahan masalah perlu ditekankan dalam pencapaian tujuan belajar khususnya berkaitan dengan materi yang memiliki kemiripan karakteristik dengan materi KK3 TKJ.

2. Penggunaan pembelajaran kooperatif tipe GI dapat digunakan lebih baik dari tipe Jigsaw II untuk meningkatkan pemahaman konsep dan pemecahan masalah untuk materi yang memiliki karakteristik pemecahan masalah seperti KK3 dengan 
tetap memperhatikan motivasi belajar TKJ para siswa, dengan kondisi kelas yang memiliki kesamaan karakteristik dengan siswa TKJ SMK 1 Sedayu.

Berdasarkan kesimpulan dan implikasi diatas, peneliti menyarankan beberapa hal-hal sebagai berikut.

1. Penelitian lanjutan dapat dilaksanakan pada materi yang sama untuk mengetahui deskripsi peningkatan pemahaman konsep dan pemecahan masalah dengan menggunakan tipe pembelajaran kooperatif tipe GI.

2. Penelitian lanjutan dapat dilaksankan pada materi yang sama untuk mengetahui dampak penggunaan pembelajaran kooperatif tidak hanya pada ranah kognitif, tetapi juga pada ranah afektif dan psikomotorik.

3. Penelitian lanjutan dapat dilaksankan pada materi yang berbeda baik dengan karakteristik materi yang sejenis maupun yang berbeda.

4. Perlu dilakukan penelitian lebih lanjut dengan mengukur tingkat kemampuan akademik siswa, IQ siswa, tingkat kemampuan materi yang terkait atau lainnya untuk dijadikan kovarian.

\section{DAFTAR PUSTAKA}

Agran, Martin. (1997). Student directed learning: teaching self-determination skills. California: Thompson Publishing Company

Anderson, L.W. \& Krathwohl, D. R (Eds). (2001). Taxonomy for learning, teaching, and assessing. Newyork: Longman.

Angelo, T.A., \& Cross, K. P. (1993). Classroon assessment technique. San Fransisco : A Wiley Imprint.

Arends, R.I. (2008). Learning to teach: belajar untuk mengajar edisi ketujuh/ buku dua (Terjemahan Helly Prajitno Soetjipto). Yogyakarta: Pustaka Pelajar.

Asropi (2008). Populasi dan sampel. Diakses tanggal 09 Juni 2013 dari http://asropi. files.wordpress.com/2008/10/populasidan-sampel.pdf
Baharuddin \& Esa Nur Wahyuni. (2007). Teori belajar dan pembelajaran. Yogyakarta: Ar-Ruzz Media

Chiappetta, E. L., \& Koballa, T. R. Jr. (2010). Science instruction in the middle and secondary schools developing fundamental knowledge and skills $\left(7^{\text {th }} e d\right)$. Boston: Allyn \& Bacon

Cook, T. D., \& Campbell, D. T. (1979). Quasi experimentation design \& issues for field settings. Chicago: Rand McNally

Dell'Olio, J.M., \& Donk, T. (2007). Models of teaching. California: Sage Publications, Inc.

Depdiknas. (2003). Penjelasan UU RI Nomor 20 tahun 2003 tentang sistem pendidikan nasional. Diaksestanggal 27 Agustus 2012, dari http://www.hukumonline. com/pusatdata/download/fl10388/paren $\mathrm{t} / 13662$

DitPSMK. (2013). Revisi pedoman penyelenggaraan uji kompetensi keahlian (ukk) smk tahun pelajaran 2012/2013. Diakses tanggal 2 Februari 2013 dari http://ditpsmk.net/download/Revisi\%20 Pedoman\%20UKK\%20tahun\%202013. pdf

Djamarah, S.B. (2008). Psikologi belajar. Jakarta: Rineka Cipta

Djemari Mardapi. (2008). Teknik penyusunan instrumen tes dan non tes. Yogyakarta: Mitra Cendekia Press

Galton, M. J., Steward, S., Hargreaves, L., et al. (2009). Motivating Your secondary Class. Sage Publications

Gall, M.D., Gall J.P., \& Borg W.R. (2007). Educational research an introduction ( $8^{\text {th }}$ edition). Boston: Allyn and Bacon

Gillies, R.M. (2007). Cooperative learning.California: Sage Publications

Hamalik, Oemar. (2009). Proses belajar mengajar. Jakarta: Bumi Aksara

Hamalik, Oemar. (2011). Kurikulum dan pembelajaran. Jakarta: Bumi Aksara

Hamzah B. Uno. (2008). Teori motivasi dan pengukurannya analisis dibidang pendidikan. Jakarta: PT Bumi Aksara 
I Wayan Santyasa. (2009). Keunggulan komparatif model perubahan konseptual dan investigasi kelompok dalam pencapaian pemahaman konsep dan pemecahan masalah fisika bagi siswa sma. Singaraja: Jurnal Penelitian Dan Pengembangan Pendidikan (JPPP) Lembaga Penelitian Universitas Pendidikan Ganesha

Jacobsen, D. A., Egen P., \& Kauchak D. (2009). Methods for teaching: metodemetode pengajaran meningkatakan belajar siswa TK-SMA. Yogyakarta: Pustaka Pelajar

Jensen, E. (2011). Pemelajaran berbasis otak. (Terjemahan Benyamin Molan). Jakarta: PT Indeks

Johnson, B. \& Christensen, L. (2008). Education research $3^{\text {rd }}$ edition.California: Sage Pulications

Joyce, B., Weil, M., \& Calhoun, E. (2009). Models of teaching model-model pengajaran (edisi delapan). (Terjemahan Achmad Fawaid). Pustaka Pelajar: Yogyakarta

M.A. Hertiavi., H. Langlang, \& S. Khanafiyah. (2010). 1104-2129-1-PB.pdf. diakses tanggal 2 Februari 2013 dari http://journal.unnes.ac.id/nju/index.php/ JPFI/article/download/1104/1015

McLean, Alan. (2009). Motivating Every Learner. Los Angeles: Sage

Mitchell, M. G., Montgomery, H., Holder, M., et al. (2008). Group investigation as a cooperative learning strategy: an integrated analysis of the literature. Diambil pada tanggal 2 Februari 2013 dari Alberta Journal of Educational Research; Winter 2008; 54, 4; Proquest Education Journals pg.388

Muhammad Nisfiannoor. (2009). Pendekatan statistika modern untuk ilmu sosial. Jakarta: Salemba Humanika.

Napitupulu, E. L. (24 Febriari 2012). Lulusan SMK siap kerja dan kuliah. Diakses tanggal 4 Juli 2012 dari http://edukasi. kompas.com/read/2012/02/24/2234329 1/Lulusan.SMK.Siap. Kerja.dan.Kuliah
Nasution, Rozaini. (2003). Teknik Sampling. Diakses tanggal 09 Juni 2013 dari http://library.usu.ac.id/download/fkm/fk m-rozaini.pdf

Nelsen Pelealu. (2013). Penggunaan metode group investigation (gi) dalam pembelajaran kooperatif guna meningkatkan hasil belajar dasar kompetensi kejuruan menggunakan alat-alat ukur siswa kelas $x$ tab smk negeri 2 bitung. Diakses tanggal 2 Februari 2013 dari http://fatek.unima.ac.id/jurnal...html

Nitko, A. J., \& Brookhart, S. M. (2011). Educational assessment of students. Boston: pearson

Pudji Muljono. (2012). KPMpjm-artik3Kajian relevansi.pdf. diambil pada 2 Februari 2013 dari http://repository. ipb.ac.id/

Reardon, T. (2001). PSS teaching problem solving strategies [versi elektronik]. Diakses tanggal 2 juli 2012, dari http://www.as.ysu.edu/ thomasr/ PSS\%20Teaching\%20Problem\%20Sol ving\%20Strategies.pdf.

Reid, G. (2009). Memotivasi siswa di kelas: gagasan dan strategi. (Terjemahan Hartati widiastuti). Jakarta: PT Indeks

Santrock, J. W. (2011). Educational psychology. ( $5^{\text {th }}$ edition). New York: McGraw Hill

Sardiman, A.M. (2011). Interaksi dan motivasi belajar mengajar. Jakarta: PT RajaGrafindo Persada

Schunk, D. H., Pintrich, P. R., \& Meece, J. L. (2010). Motivation in education: theory, research and application. New Jersey: Pearson

SMKN 1 Sedayu. (2009). Kurikulum SMK 1 sedayu. Bantul: SMK 1 Sedayu.

Sharan, S. (2012). Handbook of cooperative learning (Terjemahan Sigit Prawoto). Yogyakarta: Familia

Slavin, E. R. (1995). Cooperative learning: teory, research and practice. Massachusetts: Allyn \& Bacon 
Slavin, E. R. (2009). Cooperative learning: teori, riset dan praktek (Terjemahan Lita). Bandung: Nusa Media

Slavin, E. R. (2011). Psikologi pendidikan: teori dan praktik edisi kesembilan jilid 2 (Terjemahan Marianto Samosir). Jakarta: PT Indeks

Stevens, J. P. (2009). Applied multivariate statistics for the social sciences. fifth edition. New York: Taylor \& Francis Group

Stiggins, R \& Chappuis, J. (2012). An introduction to student-involved asessment for learning. Boston: Pearson.

Sugiyono. (2007). Statistika untuk penelitian. Bandung: Alfabeta

Sukandarrumidi. (2006). Metodologi penelitian: petunjuk praktis untuk peneliti pemula. Yogyakarta: Gadjah Mada University Press.

Sumarna Surapranata. (2005). Panduan penulisan tes tertulis implementasi kurikulum 2004. Bandung: PT Remaja Rosdakarya

Surabayapost. (4 Desember 2010). 50\% lulusan SMK belum terserap. Diakses tanggal 4 Juli 2012 dari http://www. surabayapost.co.id/..

Suwarna, S. M. (2006). Pengajaran mikro. Yogyakarta: Tiara Wacana.
Trianto. (2010). Mendesain model pembelajaran inovatif-progresif. Jakarta: Kencana

Warner, R. M. (2008). Applied statistics from bivariate through multivariate techniques. California: Sage

Wiersma, W. (1995). Research methods in education: an introduction. Massachusetts: Allyn and Bacon.

Woolfolk, A. (2007). Educational psychology. Boston: Pearson

Woolfolk, A. (2009). Educational psychology active learning edition, edisi kesepuluh buku kedua (Terjemahan Helly Prajitno Soetjipto). Yogyakarta: Pustaka Pelajar

Yani Nurhaeni. (2011). Meningkatkan pemahaman siswa pada konsep listrik melalui pembelajaran kooperatif tipe Jigsaw pada siswa kelas IX SMPN 43 Bandung. Diakses tanggal 2 Februari 2013 dari http://jurnal.upi.edu/..

Lia Y., Sudiyono, Meilina B., et al. (2011). Strategi pembelajaran untuk meningkatkan pemahaman dan keterampilan berpikir kritis (critical thinking) pada perkuliahan manajemen pendidikan melalui implementasi pembelajaran group investigation (GI). Diakses tanggal 2 Februari 2013 dari http://staff. uny.ac.id/sites/. 